J. Dairy Sci. 99:2863-2866

http://dx.doi.org/10.3168/jds.2015-10501

(C) 2016, THE AUTHORS. Published by FASS and Elsevier Inc. on behalf

of the American Dairy Science Association ${ }^{\circledR}$. This is an open access article under

the CC BY-NC-ND license (http://creativecommons.org/licenses/by-nc-nd/3.0/).

\title{
Short communication: Multi-trait estimation of genetic parameters for milk protein composition in the Danish Holstein
}

\author{
G. Gebreyesus, ${ }^{\ddagger} \ddagger$ M. S. Lund, ${ }^{*}$ L. Janss, ${ }^{*}$ N. A. Poulsen, $†$ L. B. Larsen, $†$ H. Bovenhuis, $\ddagger$ \\ and A. J. Buitenhuis*1 \\ ${ }^{*}$ Center for Quantitative Genetics and Genomics, and \\ †Department of Food Science, Aarhus University, Blichers Allé 20, PO Box 50, DK-8830 Tjele, Denmark \\ $\ddagger$ Animal Breeding and Genomics Centre, Wageningen University, PO Box 338, $6700 \mathrm{AH}$ Wageningen, the Netherlands
}

\begin{abstract}
Genetic parameters were estimated for the major milk proteins using bivariate and multi-trait models based on genomic relationships between animals. The analyses included, apart from total protein percentage, $\alpha_{\mathrm{S}^{1}}$-casein $(\mathrm{CN}), \alpha_{\mathrm{S} 2}-\mathrm{CN}, \beta-\mathrm{CN}, \kappa-\mathrm{CN}, \alpha$-lactalbumin, and $\beta$-lactoglobulin, as well as the posttranslational sub-forms of glycosylated $\kappa-\mathrm{CN}$ and $\alpha_{\mathrm{S} 1}-\mathrm{CN}-8 \mathrm{P}$ (phosphorylated). Standard errors of the estimates were used to compare the models. In total, 650 Danish Holstein cows across 4 parities and days in milk ranging from 9 to $481 \mathrm{~d}$ were selected from 21 herds. The multi-trait model generally resulted in lower standard errors of heritability estimates, suggesting that genetic parameters can be estimated with high accuracy using multitrait analyses with genomic relationships for scarcely recorded traits. The heritability estimates from the multi-trait model ranged from low $(0.05$ for $\beta-\mathrm{CN})$ to high $(0.78$ for $\kappa-\mathrm{CN})$. Genetic correlations between the milk proteins and the total milk protein percentage were generally low, suggesting the possibility to alter protein composition through selective breeding with little effect on total milk protein percentage.
\end{abstract}

Key words: genetic parameter, milk protein, multitrait model, genomic relationship

\section{Short Communication}

Milk protein composition plays an important role in the technological properties of milk (Ikonen et al., 1999; Bittante et al., 2012). Changes in relative concentrations of individual milk proteins have a major effect on milk coagulation properties (Bonfatti et al., 2011) and coagulation ability of milk is essential in cheese mak-

Received October 9, 2015.

Accepted December 10, 2015.

${ }^{1}$ Corresponding author: bart.buitenhuis@mbg.au.dk ing (Cassandro et al., 2008). The major milk proteins include $\alpha_{\mathrm{S}_{1}}-\mathrm{CN}, \alpha_{\mathrm{S} 2}-\mathrm{CN}, \beta-\mathrm{CN}, \kappa-\mathrm{CN}, \alpha-\mathrm{LA}$, and $\beta$-LG. In addition, several posttranslational modifications of these proteins exist in milk.

Previous studies have shown that considerable genetic variation exists in the composition of milk protein (Bobe et al., 1999; Schopen et al., 2009), presenting the opportunity to alter milk protein composition through selective breeding. Reliable estimates of genetic parameters, including heritability and genetic covariances, are crucial to evaluate the potential for breeding. Quantifying specific milk proteins requires specialized and costly equipment, making it difficult and expensive to measure the traits. As a result, sufficient phenotypic data are not available for reliable estimation of genetic parameters. One effective strategy to deal with such scarcely recorded traits could be implementation of multi-trait models that take advantage of information from correlated traits (Calus and Veerkamp, 2011).

Generally, only a few studies have previously estimated genetic parameters for specific milk proteins (Schopen et al., 2009; Bonfatti et al., 2011) and their posttranslational sub-forms (Bijl et al., 2014). More importantly, none of the previous studies have estimated genetic parameters for milk protein profile using multitrait analyses.

In this study, we estimated genetic parameters for the major milk proteins $\left(\alpha_{\mathrm{S}_{1}} \mathrm{CN}, \alpha_{\mathrm{S}_{2}} \mathrm{CN}, \beta-\mathrm{CN}, \kappa-\mathrm{CN}\right.$, $\alpha$-LA and $\beta$-LG), the posttranslational sub-forms (glycosylated $\kappa_{-} \mathrm{CN}$ and $\alpha_{\mathrm{S}^{-}} \mathrm{CN}-8 \mathrm{P}$, where $\mathrm{P}=$ phosphorylated serine), as well as protein percentage using bivariate and multi-trait models with genomic relationships between animals and compared standard errors of the estimated genetic parameters.

Morning milk samples were obtained from 650 cows from 21 herds in Denmark. The cows were in different stages of lactation (d 9 to 481 in milk) and parity 1 to 4. The liquid chromatography/electrospray ionizationmass spectrometry (LC/ESI-MS) methods were used 
to profile the milk proteins. Details on screening of samples and quantification of milk proteins were previously described by Jensen et al. (2012).

Of the total cows, 372 were genotyped using the BovineHD Illumina BeadChip. The remaining 278 cows were genotyped with the BovineSNP50 beadchip. Genomic DNA was extracted from ear tissue. Genotypes were subsequently imputed to full sequence in a 2-step procedure. The 278 cows genotyped with the BovineSNP50 chip were first imputed to the BovineHD (777k) level using a multi-breed reference of 3,383 animals including the $372 \mathrm{HD}$ genotyped cows used in this study. The true and imputed HD data for the 2 cow groups were then merged and imputed to the wholegenome sequence level using a multi-breed reference of 1,228 animals from the "1000 bull genomes" project (http://www.1000bullgenomes.com/) and data from Aarhus University using IMPUTE2 v2.3.1 (Howie et al., 2011).

The genomic relationship matrix was calculated as described by the first method presented in VanRaden (2008). In total, 3.7 million SNP markers spread over BTA1 to BTA29 were included to calculate the $\mathbf{G}$ matrix.

The REML approach in DMU was used to estimate genetic parameters and variance components (Madsen and Jensen, 2010). Bivariate and multi-trait analyses were performed and compared using standard errors for the estimated heritability.

The general model used was

$$
\begin{aligned}
\mathrm{y}_{i j k l}= & \mu+\operatorname{parity}_{i}+\operatorname{herd}_{j}+\mathrm{b}_{1} \times \operatorname{DIM}_{k}+\mathrm{b}_{2} \\
& \times \exp ^{-0.05 \times \text { DIM }_{k}+\operatorname{animal}_{l}+\mathrm{e}_{i j k l},}
\end{aligned}
$$

where $\mathrm{y}_{i j k l}$ was the observation of animal $l$, in parity $i$ and herd $j ; \mu$ was the fixed mean effect; $b_{1}$ was the regression coefficient for $\mathrm{DIM}_{k}$; and $\mathrm{DIM}_{k}$ was a covariate describing the effect of days $k$ in milk. Wilmink adjustment $\left(\exp ^{-0.05 \times D I M}\right)$ was used for DIM, $b_{2}$ was the regression coefficient for the Wilmink adjustment; animal ${ }_{l}$ was the random additive genetic effect based on $\mathbf{G}$ of animal $l$ with distribution $N\left(0, \mathbf{G} \sigma_{a}^{2}\right)$, and $\mathrm{e}_{i j k l}$ was the random residual effect, which was assumed to be normally distributed with $e \sim N\left(0, \mathbf{I} \sigma_{e}^{2}\right)$, where $\mathbf{G}$ is the genomic relationship matrix, I was the identity matrix, $\sigma_{a}^{2}$ was the genetic variation, and $\sigma_{e}^{2}$ was the residual variation.

The bivariate analyses were run for each milk protein analyzed in combination with protein percentage. For the multi-trait analysis, all 9 traits were fitted simultaneously. Correlations between traits were based on the multi-trait analyses.

Table 1 summarizes the descriptive statistics for the milk protein profile and the total milk protein percentage. Mean protein content in the sampled milk was $3.38 \%$. The major proteins $\left(\alpha_{\mathrm{S}_{1}-} \mathrm{CN}, \alpha_{\mathrm{S}_{2}} \mathrm{CN}, \beta-\mathrm{CN}\right.$, $\kappa-\mathrm{CN}, \alpha-\mathrm{LA}$, and $\beta$-LG) made up $83 \%$ of the total milk protein fraction. The caseins constituted $72.3 \%$ of the total protein, with $\beta$-CN and $\alpha_{\mathrm{S}_{1}} \mathrm{CN}$ alone contributing to 34.1 and $26.8 \%$ of the total milk protein, respectively. The whey proteins constituted $10.8 \%$ of the total protein.

The $\alpha_{\mathrm{S} 1}-\mathrm{CN}-8 \mathrm{P}$ accounted for $19.2 \%$ of the total milk protein and $71.6 \%$ of the $\alpha_{S_{1}}-\mathrm{CN}$ fraction of the total protein percentage. This was comparable to previous findings, in which $\alpha_{\mathrm{S} 1}-\mathrm{CN}-8 \mathrm{P}$ accounted for $21.3 \%$ of the total protein (Bijl et al., 2014) and $74 \%$ of the $\alpha_{\mathrm{S} 1}-\mathrm{CN}$ (Heck et al., 2008) in the Dutch Holstein population.

Heritability values and standard errors of estimation from the bivariate and multi-trait models are given in Table 2. Generally, the heritability estimates for the milk proteins were moderate to high except for $\beta$-CN, which had the lowest estimates (0.01-0.05). Glycosyl-

\begin{tabular}{|c|c|c|c|c|}
\hline Protein or fraction ${ }^{2}$ & Mean (\%) & $\mathrm{CV}(\%)$ & $5 \%$ quantile & $95 \%$ quantile \\
\hline$\alpha_{\mathrm{S} 1}-\mathrm{CN}$ & 26.8 & 9 & 25.5 & 28.1 \\
\hline$\alpha_{S_{1}}-\mathrm{CN}-8 \mathrm{P}$ & 19.2 & 11 & 17.7 & 20.7 \\
\hline$\alpha_{\mathrm{S}_{2}}-\mathrm{CN}$ & 5.3 & 20 & 4.5 & 5.9 \\
\hline$\beta-\mathrm{CN}$ & 34.1 & 10 & 31.5 & 36.7 \\
\hline$\kappa-C N$ & 6.1 & 18 & 5.3 & 6.9 \\
\hline Glycosylated $\kappa-\mathrm{CN}$ & 1.7 & 47 & 1.2 & 2.0 \\
\hline$\alpha-\mathrm{LA}$ & 3.3 & 19 & 2.9 & 3.6 \\
\hline$\beta-L G$ & 7.5 & 21 & 6.5 & 8.4 \\
\hline Total protein $(\%)$ & 3.38 & 9 & 3.20 & 3.55 \\
\hline
\end{tabular}

Table 1. Descriptive statistics ${ }^{1}$ of milk protein profile and the total milk protein percentage 
Table 2. Heritability values and standard errors of heritability estimates

\begin{tabular}{|c|c|c|c|c|}
\hline \multirow[b]{2}{*}{ Trait } & \multicolumn{2}{|c|}{ Bivariate model } & \multicolumn{2}{|c|}{ Multi-trait model } \\
\hline & $h^{2}$ & $\mathrm{SE}$ & $\mathrm{h}^{2}$ & $\mathrm{SE}$ \\
\hline$\overline{\alpha_{S-}-\mathrm{CN}-8 \mathrm{P}^{1}}$ & 0.13 & 0.10 & 0.15 & 0.09 \\
\hline$\alpha_{\mathrm{S} 1}-\mathrm{CN}$ & 0.14 & 0.10 & 0.14 & 0.09 \\
\hline$\alpha_{\mathrm{S} 2}-\mathrm{CN}$ & 0.36 & 0.10 & 0.36 & 0.10 \\
\hline$\beta-\mathrm{CN}$ & 0.01 & 0.07 & 0.05 & 0.08 \\
\hline Glycosylated к-CN & 0.44 & 0.10 & 0.44 & 0.09 \\
\hline$\kappa-\mathrm{CN}$ & 0.79 & 0.09 & 0.78 & 0.08 \\
\hline$\alpha-\mathrm{LA}$ & 0.22 & 0.11 & 0.25 & 0.10 \\
\hline$\beta-\mathrm{LG}$ & 0.56 & 0.11 & 0.54 & 0.10 \\
\hline Total protein $(\%)$ & 0.53 & 0.11 & 0.59 & 0.10 \\
\hline
\end{tabular}

${ }^{1}$ Where $\mathrm{P}=$ phosphorylated serine.

ated $\kappa-\mathrm{CN}(0.44)$ and $\alpha_{\mathrm{S}_{2}} \mathrm{CN}(0.36)$ had moderate heritability values estimated using the 2 models; $\kappa-\mathrm{CN}$ had the highest heritability estimates in both models (0.78-0.79).

Generally, standard errors were lower for heritability estimates using the multi-trait model for all traits except $\beta$-CN. The standard errors of estimation from the multi-trait model in the current study (0.08-0.10) were also lower compared with previous studies, including that of Schopen et al. (2009; 0.08-0.12), Buitenhuis et al. (2014; 0.12-0.21), and Bobe et al. (1999; 0.07-0.12). Given the observed medium to high genetic correlations between the proteins, the multi-trait analyses might have benefitted from use of information from correlated traits.

Heritability values estimated with the multi-trait model were comparable to estimates from previous studies. Intraherd heritability of 0.66 for total protein and 0.64 for $\kappa-\mathrm{CN}$ estimated by Schopen et al. (2009) were comparable to the current estimates of 0.59 and 0.78 , respectively. The estimates for $\alpha_{\mathrm{S}_{2}} \mathrm{CN}(0.36)$ in the current study were also comparable to the earlier reported value of 0.30 (Ikonen et al., 1997) but lower than estimates of Schopen et al. (2009; 0.73). $\beta$-Casein had the lowest heritability estimate (0.05) in this study.
This was in agreement with previous estimates for $\beta$-CN by Buitenhuis et al. (2014; 0.05), but considerably lower than estimates by Ikonen et al. (1997; 0.33 to 0.40$)$ and Schopen et al. (2009; 0.25).

Genetic and phenotypic correlations estimated using multi-trait analysis are given in Table 3. Generally, the milk protein compositions had low to medium genetic correlation with total protein $(-0.02-0.32)$. Higher genetic $(0.75)$ as well as phenotypic $(0.61)$ correlations were also observed between the 2 whey proteins ( $\beta$-LG and $\alpha-\mathrm{LA}$ ).

The genetic correlation between $\alpha_{\mathrm{S} 1}-\mathrm{CN}-8 \mathrm{P}$ and $\beta-\mathrm{LG}$ was low (-0.01). Bijl et al. (2014) have previously reported a distinct effect of $\beta$-LG protein variants and $\beta$-LG concentration on $\alpha_{\mathrm{S1}^{-}} \mathrm{CN}-8 \mathrm{P}$ concentration. Nonetheless, according to Bijl et al. (2014), the mechanism behind the established association between $\beta$-LG protein variants, as well as $\beta-\mathrm{LG}$ concentration and $\alpha_{\mathrm{S1}} \mathrm{CN}-8 \mathrm{P}$ concentration remains unclear, calling for further study.

Genetic correlations between the milk proteins and the total milk protein percentage were generally low, except for $\alpha_{\mathrm{S} 1}-\mathrm{CN}-8 \mathrm{P}(0.38)$ and $\beta-\mathrm{LG}(0.27)$.

Our results suggest that genetic parameters can be estimated with high accuracy for scarcely recorded

Table 3. Genetic (above diagonal) and phenotypic (below diagonal) correlations ${ }^{1}$

\begin{tabular}{|c|c|c|c|c|c|c|c|c|c|}
\hline Trait $^{2}$ & $\alpha_{\mathrm{S} 1}-\mathrm{CN}-8 \mathrm{P}$ & $\alpha_{\mathrm{S} 1}-\mathrm{CN}$ & $\alpha_{\mathrm{S} 2}-\mathrm{CN}$ & $\beta-\mathrm{CN}$ & Glyc к-CN & $\kappa-\mathrm{CN}$ & $\alpha-L A$ & $\beta-\mathrm{LG}$ & $\begin{array}{c}\text { Total } \\
\text { protein }(\%)\end{array}$ \\
\hline$\alpha_{\mathrm{S} 1^{-}} \mathrm{CN}-8 \mathrm{P}$ & & 0.80 & -0.06 & -0.49 & -0.39 & -0.19 & -0.43 & -0.01 & 0.38 \\
\hline$\alpha_{\mathrm{S} 1}-\mathrm{CN}$ & 0.86 & & -0.45 & -0.18 & -0.33 & -0.33 & -0.32 & -0.09 & 0.20 \\
\hline$\beta-\mathrm{CN}$ & 0.42 & 0.48 & 0.04 & & 0.28 & 0.38 & 0.06 & 0.04 & -0.10 \\
\hline Glyc к-CN & -0.04 & 0.03 & 0.02 & 0.05 & & 0.81 & 0.17 & -0.04 & -0.03 \\
\hline$\kappa-\mathrm{CN}$ & 0.20 & 0.16 & 0.05 & 0.22 & 0.68 & & 0.01 & -0.02 & 0.12 \\
\hline Total protein (\%) & 0.17 & 0.02 & 0.12 & -0.05 & 0.09 & 0.18 & -0.04 & 0.14 & \\
\hline
\end{tabular}

\footnotetext{
${ }^{2} \mathrm{P}=$ phosphorylated serine; Glyc $=$ glycosylated.
} 
traits using multi-trait analysis with genomic relationships between animals. Lower genetic correlations between the milk proteins with total protein percentage reported in this study also suggest that altering milk protein compositions through selective breeding might have little or no effect on the total protein percentage.

\section{ACKNOWLEDGMENTS}

The authors acknowledge help from Rasmus Froberg Brøndum during the imputations of genotype data. This research was supported by the Center for Genomic Selection in Animals and Plants (GenSAP) funded by The Danish Council for Strategic Research). The study used data from Danish-Swedish Milk Genomics Initiative (www.milkgenomics.dk), as well as the Milk Levy Fund (Denmark) projects "Phenotypic and genetic markers for specific milk quality parameters" and "The importance of the metagenome for milk composition and quality." A. J. B., N. A. P., and L. B. L. were supported by the project "Breeding high value milk: BIG MILK" of the Milk Levy Fund, Denmark (2015-2018). G. G. is enrolled in the Erasmus- Mundus joint doctorate European Graduate School in Animal Breeding and Genetics.

\section{REFERENCES}

Bijl, E., H. J. F. van Valenberg, T. Huppertz, A. C. M. van Hooijdonk, and $H$. Bovenhuis. 2014. Phosphorylation of $\alpha_{\mathrm{S}^{-}}$-casein is regulated by different genes. J. Dairy Sci. 97:7240-7246.

Bittante, G., M. Penasa, and A. Cecchinato. 2012. Invited review: Genetics and modeling of milk coagulation properties. J. Dairy Sci. 95:6843-6870.

Bobe, G., D. C. Beitz, A. E. Freeman, and G. L. Lindberg. 1999. Effect of milk protein genotypes on milk protein composition and its genetic parameter estimates. J. Dairy Sci. 82:2797-2804.
Bonfatti, V., A. Cecchinato, L. Gallo, A. Blasco, and P. Carnier. 2011. Genetic analysis of detailed milk protein composition and coagulation properties in Simmental cattle. J. Dairy Sci. 94:5183-5193.

Buitenhuis, A. J., N. A. Poulsen, and L. B. Larsen. 2014. Estimation of genetic parameters for the protein profile in Danish Holstein milk. Proc. 10th World Congr. Genet. Appl. Livest. Prod. https:// asas.org/docs/default-source/wcgalp-posters/614_paper_9289_ manuscript_543_0.pdf?sfvrsn $=2$.

Calus, M. P. L., and R. F. Veerkamp. 2011. Accuracy of multi-trait genomic selection using different methods. Genet. Sel. Evol. 43:26.

Cassandro, M., A. Comin, M. Ojala, R. Dal Zotto, M. De Marchi, L. Gallo, P. Carnier, and G. Bittante. 2008. Genetic parameters of milk coagulation properties and their relationships with milk yield and quality traits in Italian Holstein cows. J. Dairy Sci. 91:371376.

Heck, J. M. L., C. Olieman, A. Schennink, H. J. F. van Valenberg, and M. H. P. W. Visker. 2008. Estimation of variation in concentration, phosphorylation and genetic polymorphism of milk proteins using capillary zone electrophoresis. Int. Dairy J. 18:548-555.

Howie, B., J. Marchini, and M. Stephens. 2011. Genotype imputation with thousands of genomes. G3 (Bethesda) 1:457-470. http:// dx.doi.org/http://dx.doi.org/10.1534/g3.111.001198.

Ikonen, T., K. Ahlfors, R. Kempe, M. Ojala, and O. Ruottinen. 1999. Genetic parameters for the milk coagulation properties and prevalence of noncoagulating milk in Finnish dairy cows. J. Dairy Sci. 82:205-214.

Ikonen, T., M. Ojala, and E.-L. Syväoja. 1997. Effects of composite casein and beta-lactoglobulin genotypes on renneting properties and composition of bovine milk by assuming an animal model. Agric Food Sci. Finl. 6:283-294.

Jensen, H. B., N. A. Poulsen, K. K. Andersen, M. Hammershoj, and H. D. Poulsen. 2012. Distinct composition of bovine milk from Jersey and Holstein-Friesian cows with good, poor, or noncoagulation properties as reflected in protein genetic variants and isoforms. J. Dairy Sci. 95:6905-6917.

Madsen, P., and J. Jensen. 2010. A User's Guide to DMU. Version 6 , Release 5.0. University of Aarhus, Faculty Agricultural Sciences (DJF), Department of Genetics and Biotechnology, Research Centre Foulum, Tjele, Denmark.

Schopen, G. C., J. M. Heck, H. Bovenhuis, M. H. Visker, H. J. van Valenberg, and J. A. van Arendonk. 2009. Genetic parameters for major milk proteins in Dutch Holstein-Friesians. J. Dairy Sci. 92:1182-1191.

VanRaden, P. M. 2008. Efficient methods to compute genomic predictions. J. Dairy Sci. 91:4414-4423. 